Journal of Experimental and Clinical Medicine https://dergipark.org.tr/omujecm

Research Article

J Exp Clin Med

2021; 38(4): 490-495

doi: $10.52142 /$ omujecm.38.4.17

\title{
Which COVID-19 patients should be recommended for home isolation and which should be hospitalized? Predictors of disease progression for mild COVID-19 patients
}

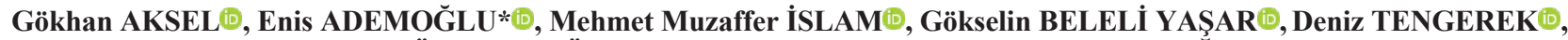

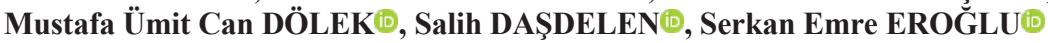 \\ Department of Emergency Medicine, Umraniye Training and Research Hospital, University of Health Sciences, Istanbul, Turkey
}

\begin{abstract}
\begin{tabular}{ccccc}
\hline Received: 14.03 .2021 & $\bullet$ & Accepted/Published Online: 27.03 .2021 & - Final Version: 30.08 .2021 \\
\hline
\end{tabular}
\section{Abstract}

Each country has different treatment and home isolation recommendations regarding the management of mild COVID-19 patients, and there is not yet a standard approach. The aim of this study is to determine which patients are suitable for home isolation by identifying the variables that predict the progression of the disease in mild COVID-19 patients. This prospective observational study included laboratory confirmed mild COVID-19 patients older than 18 years. The primary outcome of the study was the disease progression in mild COVID-19 patients. A multivariate regression model was created according to the results of univariate analyses. A total of 254 patients included in the study. Median age of the patients was 34.5 years (27-42), and 132 (52\%) of them were male. COVID-19 compatible thoracic computed tomography appearance $(\mathrm{P}<0.001, \mathrm{HR}=6.58,95 \% \mathrm{CI}=2.60-16.65)$ and advanced age $(\mathrm{P}=0.008, \mathrm{HR}=1.07,95 \% \mathrm{CI}=1.02-1.13)$ were significantly associated with the progression of the disease, and the use of hydroxychloroquine $(\mathrm{P}=0.002, \mathrm{HR}=0.09,95 \% \mathrm{CI}=0.02-0.32)$ was significantly associated with a decrease in the disease progression. The advanced age and COVID-19 compatible thoracic computed tomography appearance were associated with progression of the disease, while hydroxychloroquine treatment was associated with decreased progression in mild COVID-19 patients.
\end{abstract}

Keywords: 2019 novel coronavirus disease, clinical deterioration, COVID-19 pandemic, disease progressions, SARS-CoV-2 infection

\section{Introduction}

On December 31, 2019, pneumonia cases with an unknown cause were reported from Wuhan, China. On March 11, 2020, the World Health Organization (WHO) declared a pandemic on the outbreak, which was officially understood to be caused by a new coronavirus strain (COVID-19) with the isolation of the novel coronavirus (n-CoV) on January 7, $2020(1,2)$. According to the latest WHO reports, on September 5, 2020, there were $26,415,380$ cases associated with COVID-19 seen worldwide, and 870,286 deaths were reported (3).

COVID-19 may present as asymptomatic or mild; it may progress to adult respiratory distress syndrome (ARDS) or septicemia as well. While most of the patients experience the disease as so mild, they can be followed in home isolation, others require hospitalization (4). Since the beginning of the pandemic, many countries have been regularly updating their national guidelines according to the data in the available literature (5-9). However, since there is still not sufficient knowledge to create a clear understanding regarding the criterion for home isolation with this new disease, there are significant differences between the guidelines. Regarding prevention recommendations, for example, according to the Centers for Disease Control and Prevention (CDC), home isolation is recommended for the elderly and patients with comorbidities as long as they have a mild or moderate prognosis (those without hypoxemia and severe pneumonia). However, according to the Turkish Ministry of Health, regardless of disease severity, home isolation is not recommended for the elderly and patients with comorbidity. In contrast, the National Health Commission of the People's Republic of China recommends hospital admission for every patient diagnosed or suspected of COVID-19, regardless of age or disease severity $(4,8,9)$.

To determine which patients are appropriate for home isolation and which are appropriate for hospital admission, in this study, we aimed to determine the variables predicting clinical deterioration in patients with laboratory confirmed mild COVID-19.

\section{Materials and methods}

\subsection{Study design and setting}

This prospective observational study was carried out between April 1, 2020, and May 9, 2020, in an emergency medicine department (ED) of a tertiary care training and research hospital. Ethical approval was obtained from Ümraniye Training and Research Hospital Clinical Research Ethics Committee. 


\subsection{Selection of participants}

Adult mild COVID-19 patients were consecutively included in the study. The definition of mild COVID-19 included patients with symptoms such as fever, myalgia, cough, shortness of breath, sore throat, nasal congestion, headache, diarrhea, or loss of smell/taste, and with none of the following severe disease criteria: age of $>50$ years, chest radiography or thoracic computed tomography revealing bilateral diffuse parenchymal infiltration, an $\mathrm{O}_{2}$ saturation below $93 \%$ in room air, tachypnea ( $>22 / \mathrm{min})$, the presence of comorbid diseases (chronic lung disease, immunity disorders, hypertension, malignancy, diabetes mellitus), or poor prognostic criteria in laboratory tests (D-Dimer $>1000 \mathrm{ng} / \mathrm{ml}$, blood lymphocyte count $<800 / \mu \mathrm{l}$, C-reactive protein $(\mathrm{CRP})>40 \mathrm{mg} / \mathrm{L}$ or ferritin $>500 \mathrm{ng} / \mathrm{ml}$ ) (9). Patients with those severe disease criteria were admitted to the hospital and excluded from the study. The medical treatment recommended in the guidelines published by the Ministry of Health (hydroxychloroquine 2x $200 \mathrm{mg}$ for five days) was started and home isolation was recommended for patients who fit the mild COVID-19 definition. These patients were followed both by the Ministry of Health screening teams and by the hospital by phone. Patients who described any worsening in their clinical condition during their follow-up were called back to the hospital. After the re-evaluations, patients who met the abovementioned severe disease criteria were accepted as progression of the disease and were hospitalized. Patients with at least one positive COVID-19 polymerase chain reaction (PCR) test result were included in the study. All patients with negative results, or who were younger than 18 years old, pregnant, had any abnormal vital signs (pulse, respiratory rate, arterial blood pressure, fever), who refused to participate in the study or had a lack of data were excluded from the study.

\subsection{Measurements}

The baseline characteristics of the included patients, complaints, close contact history, smoking status, home isolation status, another COVID-19 case in the household, thoracic computed tomography or chest radiography findings, and clinical deterioration during follow-up (requiring hospitalization) and treatments were recorded. Although hydroxychloroquine treatment is routinely initiated in all these patients as per the standard protocol in the country, some patients refused to use drugs due to their individual preferences, which was recorded during the follow-up. All patients were called daily and the presence of symptom worsening was questioned. Patients who described progression compared to their symptoms at the time of first admission were called back to the hospital and were reevaluated. Patients who met the moderate-severe COVID-19 criteria were considered as patients with clinical progression. The clinical deterioration decision was made based on the moderate-severe COVID-19 criteria defined in the diagnosis and treatment of COVID-19 guideline published by Turkish Ministry of Health. Accordingly, if any of the following criteria was present, the patient was accepted as deteriorated and was hospitalized; not all COVID-19 related pneumonia but chest radiography or thoracic computed tomography revealing bilateral diffuse parenchymal infiltration, an $\mathrm{O} 2$ saturation below $93 \%$ in room air, tachypnea ( $>22 / \mathrm{min}$ ), or poor prognostic criteria in laboratory tests (D-Dimer $>1000$ $\mathrm{ng} / \mathrm{ml}$, blood lymphocyte count $<800 / \mu \mathrm{l}$, C-reactive protein (CRP) $>40 \mathrm{mg} / \mathrm{L}$ or ferritin $>500 \mathrm{ng} / \mathrm{ml}$ ) (9).

\subsection{Outcome measures}

The primary outcome was disease progression in mild COVID-19 patients. We aimed to determine which variables predicted the progression of the disease.

\subsection{Statistical analysis}

Statistical analyses were performed using SPSS 26 (IBM Corp. Released 2019. IBM SPSS Statistics for Windows, Version 26.0. Armonk, NY: IBM Corp). The distribution of normality for the continuous variables was tested with the Shapiro-Wilk test. The Student's T-test or Mann-Whitney U tests were used to compare groups. Chi-square and Fisher's exact tests were used for comparison of the categorical data. To determine the variables affecting disease progression, a multivariate regression model was created using variables having $p$ values of $<0.2$ in univariate analyses. A two-tailed $p$ value of $<0.05$ was considered statistically significant.

\section{Results}

After 569 patients were enrolled in our study, exclusion criteria were applied, and the remaining 254 patients were included in the study. The patient flow chart is given in (Fig. $1)$.

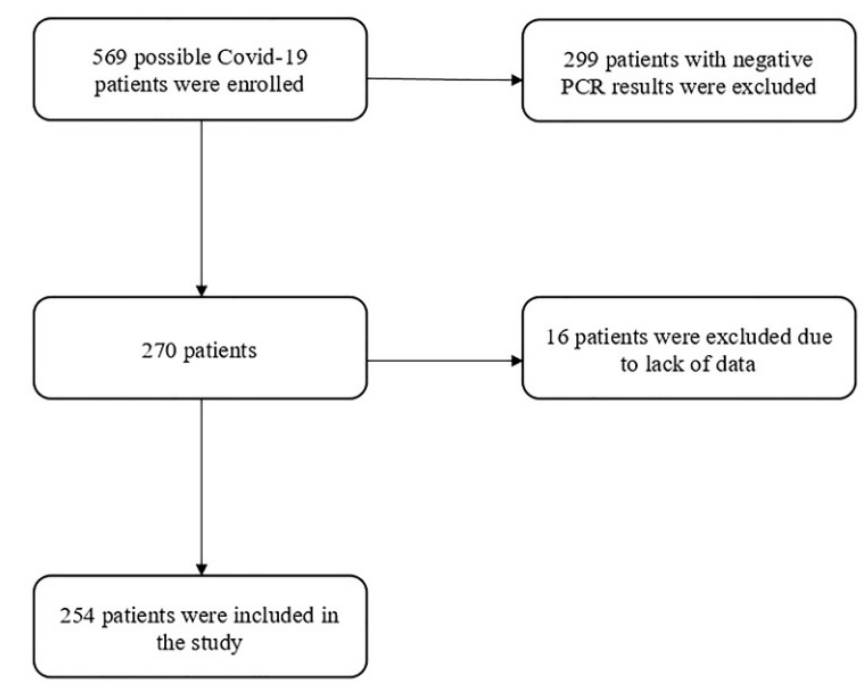

Fig. 1. Patient flow chart

The median age of the patients was 34.5 years $(27-42)$, and $132(52 \%)$ of them were male. The basic characteristics of the patients are shown in Table 1 . The patients included in the study were divided into two groups: Group 1: patients whose disease did not progress (those who completed their treatment and follow-up in home isolation) and Group 2: patients whose disease progressed (those who required reevaluation and then hospitalized). 
Table 1. Basic characteristics of the patients

\begin{tabular}{|c|c|}
\hline Variable & $\begin{array}{l}\text { N } \quad(\%) / \text { Median } \\
\text { (IQR) }\end{array}$ \\
\hline Age, year & $34.5(27-42)$ \\
\hline Gender, female & $122(48)$ \\
\hline $\begin{array}{l}\text { Patients with close contact history with } \\
\text { Covid-19 }\end{array}$ & $115(45.3)$ \\
\hline \multicolumn{2}{|l|}{ Home isolation } \\
\hline Strict isolation (patient lives alone) & $54(21.3)$ \\
\hline $\begin{array}{l}\text { Limited isolation (Isolation in a } \\
\text { single room but in the same house } \\
\text { with the family) }\end{array}$ & $117(46.1)$ \\
\hline $\begin{array}{l}\text { Poor isolation (Lives in the same } \\
\text { house and room) }\end{array}$ & $83(32.7)$ \\
\hline \multicolumn{2}{|l|}{$\begin{array}{l}\text { Another Covid-19 case in the } \\
\text { household }\end{array}$} \\
\hline No other Covid-19 case & $121(47.6)$ \\
\hline $\begin{array}{l}\text { There is case of Covid-19 before the } \\
\text { patient }\end{array}$ & $69(27.2)$ \\
\hline $\begin{array}{l}\text { There is case of Covid-19 after the } \\
\text { patient }\end{array}$ & $27(10.6)$ \\
\hline There is concurrent case of Covid-19 & $37(14.6)$ \\
\hline Smokers (current or former) & $87(34.3)$ \\
\hline Healthcare professionals & $25(9.8)$ \\
\hline \multicolumn{2}{|l|}{ Symptoms } \\
\hline Fever & $92(36.2)$ \\
\hline Cough & $158(62.2)$ \\
\hline Shortness of breath & $65(25.6)$ \\
\hline Myalgia & $78(30.7)$ \\
\hline Fatigue & $84(33.1)$ \\
\hline Loss of smell & $32(12.6)$ \\
\hline Loss of taste & $28(11)$ \\
\hline Diarrhea & $15(5.9)$ \\
\hline Nausea & $14(5.5)$ \\
\hline Vomiting & $5(2)$ \\
\hline Hemoptysis & $2(0.8)$ \\
\hline Headache & $42(16.5)$ \\
\hline Sore throat & $37(14.6)$ \\
\hline Nasal congestion & $16(6.3)$ \\
\hline Conjunctivitis & $13(5.1)$ \\
\hline Asymptomatic & $24(9.4)$ \\
\hline \multicolumn{2}{|l|}{ Treatments } \\
\hline Hydroxychloroquine & $236(92.9)$ \\
\hline Oseltamivir & $59(23.2)$ \\
\hline Azithromycin & $12(4.7)$ \\
\hline Clarithromycin & $3(1.2)$ \\
\hline Other antibiotics & $3(1.2)$ \\
\hline Patients undergoing thoracic CT & $148(58.3)$ \\
\hline $\begin{array}{l}\text { Findings compatible with Covid-19 } \\
\text { in thoracic CT (for } 148 \text { patients) }\end{array}$ & $55(37.2)$ \\
\hline $\begin{array}{l}\text { Patients with clinical deterioration } \\
\text { during follow-up (primary outcome) }\end{array}$ & $29(11.4)$ \\
\hline
\end{tabular}

CT; Computer tomography

In the univariate analysis, it was observed that COVID-19 compatible thoracic CT appearance and cough were statistically significantly associated with increased clinical progression, while the use of hydroxychloroquine was significantly associated with decreased clinical progression. In the multivariate logistic regression analysis, it was observed that COVID-19 compatible thoracic CT appearance and advanced age were significantly associated with the progression of the disease, while the use of hydroxychloroquine was significantly associated with decreased progression of the disease. The results of the univariate and the multivariate analyses are provided in Table

2. When the patients were divided into two groups according to the use of hydroxychloroquine, no statistically significant difference was observed between the groups in terms of basic characteristics such as age, gender, close contact history, smoking status, symptoms, or COVID-19 compatible thoracic CT appearance. Descriptive data of the hydroxychloroquine groups are provided in Table 3. No death was observed in any of the patients included in the study.

\section{Discussion}

In our study, none of the patients died who were initially recommended home isolation according to the guidelines of the Turkish Ministry of Health. From this perspective, it can be interpreted that the Ministry of Health's definition of mild COVID-19 is appropriate. However, considering that $11.4 \%$ of the patients had clinical deterioration, the current guideline might still require revision. According to the current data published by WHO, the number of deaths per million is as follows in some countries: Belgium 855, Spain 629, UK 612, Italy 588, US 567, Brazil 594, France 468, Turkey 78, South Korea 6, and China 3 (3). However, comparing the mortality rates of the countries based on the available data is a contentious issue because the PCR indications, treatment, and patient management policies are not standardized between the countries. Nevertheless, the low mortality rates in countries such as Turkey, China, and South Korea is striking. Regardless of the severity of the disease, early initiation of treatment with hydroxychloroquine of all patients with COVID-19 may be one of the causes of the low mortality rate in Turkey. The most striking finding of our study is the hazard ratio of not using hydroxychloroquine as 11.4. Although the patients in our study were not randomized in terms of hydroxychloroquine use, the fact that there was no difference between the hydroxychloroquine groups in terms of basic characteristics makes this finding remarkable.

The use of hydroxychloroquine in the treatment of COVID-19 is controversial (10). In vitro experiments have shown that hydroxychloroquine inhibits the SARSCoV2 virus (11). In a randomized controlled study, it was found that prophylactic hydroxychloroquine treatment initiated within the first four days after exposure did not prevent the disease in individuals with high and moderate COVID-19 exposure (12). When compared to standard therapy in a randomized controlled study, it was found that hydroxychloroquine use did not make a significant difference in the elimination (negativity) of the disease in hospitalized treatment-resistant mild-to-moderate COVID-19 patients (13). 
Aksel et al. / J Exp Clin Med

Table 2. Univariate and multivariate analysis of variables associated with progression of disease in patients with mild Covid-19

\begin{tabular}{|c|c|c|c|c|c|c|}
\hline \multirow[b]{2}{*}{ Variable } & \multirow{2}{*}{$\begin{array}{c}\text { Group 1 } \\
\text { (Non- } \\
\text { progression) } \\
\text { N (\%) / } \\
\text { Median } \\
\text { (IQR) }\end{array}$} & \multirow{2}{*}{$\begin{array}{c}\text { Group 2 } \\
\text { (Disease } \\
\text { progression) } \\
\text { N (\%)/ } \\
\text { Median } \\
\text { (IQR) }\end{array}$} & \multicolumn{2}{|c|}{ Univariate Analysis } & \multicolumn{2}{|c|}{ Multivariate Analysis } \\
\hline & & & HR $(95 \%$ CI) & $P$ value & HR $(95 \%$ CI $)$ & P value \\
\hline Age, years & $34(27-42)$ & $39(34-45)$ & $0.366(0.047-2.835)$ & 0,484 & $\begin{array}{c}1.070 \\
(1.018-1.126)\end{array}$ & 0.008 \\
\hline Age $<50$ & $205(91.1)$ & $28(96.6)$ & $0.366(0.047-2.835)$ & 0.484 & - & - \\
\hline Gender, female & $108(48)$ & $14(48.3)$ & $1.011(0.466-2.192)$ & 0.978 & - & - \\
\hline $\begin{array}{l}\text { Patients with close } \\
\text { contact history }\end{array}$ & $103(45.8)$ & $12(41.4)$ & $0.836(0.382-1.832)$ & 0.654 & - & - \\
\hline $\begin{array}{l}\text { Strict home } \\
\text { isolation is provided }\end{array}$ & $47(20.9)$ & $7(24.1)$ & $1.205(0.485-2.991)$ & 0.687 & - & - \\
\hline $\begin{array}{l}\text { Smokers (current or } \\
\text { former) }\end{array}$ & $79(34.7)$ & $9(31.0)$ & $0.848(0.369-1.951)$ & 0.698 & - & - \\
\hline $\begin{array}{l}\text { Healthcare } \\
\text { professionals }\end{array}$ & $22(9.8)$ & $3(10.3)$ & $1.065(0.298-3.805)$ & 1 & - & - \\
\hline \multicolumn{7}{|l|}{ Symptoms } \\
\hline Fever & $77(34.2)$ & $15(51.7)$ & $2.059(0.945-4.487)$ & 0.065 & $\begin{array}{c}2.507 \\
(0.971-6.470)\end{array}$ & 0,057 \\
\hline Cough & $135(60)$ & $23(79.3)$ & $2.556(1.001-6.524)$ & 0.044 & $\begin{array}{c}1.737 \\
(0.612-4.927)\end{array}$ & 0.299 \\
\hline Shortness of breath & $58(25.8)$ & $7(24.1)$ & $0.916(0.372-2.257)$ & 0.849 & - & - \\
\hline Myalgia & $72(32)$ & $6(20.7)$ & $0.554(0.216-1.421)$ & 0.214 & - & - \\
\hline Fatigue & $72(32)$ & $12(41.4)$ & $1.500(0.681-3.306)$ & 0.312 & - & - \\
\hline Loss of smell & $30(13.3)$ & $2(6.9)$ & $0.481(0.109-2.130)$ & 0.550 & - & - \\
\hline Loss of taste & $26(11.6)$ & $2(6.9)$ & $0.567(0.127-2.524)$ & 0.752 & - & - \\
\hline Diarrhea & $12(5.3)$ & $3(10.3)$ & $2.048(0.542-7.737)$ & 0.391 & - & - \\
\hline Nausea & $11(4.9)$ & $3(10.3)$ & $2.245(0.588-8.572)$ & 0.205 & - & - \\
\hline Vomiting & $3(1.3)$ & $2(6.9)$ & $\begin{array}{c}5.481 \\
(0.876-34.283)\end{array}$ & 0.101 & $\begin{array}{c}11.962 \\
(0.733-195.177)\end{array}$ & 0.082 \\
\hline Hemoptysis & $2(0.9)$ & $0(0)$ & $\begin{array}{c}1.515 \\
(0.071-32.336)\end{array}$ & 1 & - & - \\
\hline Headache & $39(17.3)$ & $3(10.3)$ & $0.550(0.159-1.909)$ & 0.434 & - & - \\
\hline Sore throat & $30(13.3)$ & $7(24.1)$ & $2.068(0.813-5.259)$ & 0.157 & $\begin{array}{c}1.812 \\
(0.608-5.404)\end{array}$ & 0.286 \\
\hline Nasal congestion & $15(6.7)$ & $1(3.4)$ & $0.500(0.064-3.932)$ & 1 & - & - \\
\hline Conjunctivitis & $11(4.9)$ & $2(6.9)$ & $1.441(0.303-6.851)$ & 0.649 & - & - \\
\hline Asymptomatic & $23(10.2)$ & $1(3.4)$ & $0.314(0.041-2.414)$ & 0.329 & - & - \\
\hline $\begin{array}{l}\text { Patients given } \\
\text { hydroxychloroquine } \\
\text { treatment }\end{array}$ & $214(95.1)$ & $22(75.9)$ & $0.162(0.057-0.459)$ & 0.002 & $\begin{array}{c}0.087 \\
(0.024-0.321)\end{array}$ & $<0.001$ \\
\hline $\begin{array}{l}\text { Findings compatible } \\
\text { with Covid-19 in } \\
\text { thoracic computed } \\
\text { tomography }\end{array}$ & $39(17.3)$ & $16(55.2)$ & $\begin{array}{c}5.870 \\
(2.613-13.184)\end{array}$ & $<0.001$ & $\begin{array}{c}6.577 \\
(2.599-16.646)\end{array}$ & $<0.001$ \\
\hline
\end{tabular}

HR; Hazard ratio, IQR; Interquartile range, CI; Confidence interval 
Table 3. Basic descriptive data of hydroxychloroquine use groups

\begin{tabular}{|c|c|c|c|}
\hline Variable & Use of hydroxychloroquine & Non-use of hydroxychloroquine & $P$ value \\
\hline Age, year & $34(27-43)$ & $38(29.5-39)$ & 0.958 \\
\hline Gender, female & $114(48.3)$ & $8(44.4)$ & 0.752 \\
\hline $\begin{array}{l}\text { Patients with close contact } \\
\text { history }\end{array}$ & $108(45.8)$ & $7(38.9)$ & 0.572 \\
\hline $\begin{array}{l}\text { Patients providing strict home } \\
\text { isolation }\end{array}$ & $50(21.2)$ & $4(22.2)$ & 1 \\
\hline Smokers (current or former) & $79(33.5)$ & $8(44.4)$ & 0.344 \\
\hline Healthcare professionals & $24(10.2)$ & $1(5.6)$ & 1 \\
\hline \multicolumn{4}{|l|}{ Symptoms } \\
\hline Fever & $89(37.7)$ & $3(16.7)$ & 0.073 \\
\hline Cough & $147(62.3)$ & $11(61.1)$ & 0.921 \\
\hline Shortness of breath & $60(25.4)$ & $5(27.8)$ & 0.784 \\
\hline Myalgia & $75(31.8)$ & $3(16.7)$ & 0.180 \\
\hline Fatigue & $80(33.9)$ & $4(22.2)$ & 0.310 \\
\hline Loss of smell & $32(13.6)$ & $0(0)$ & 0.140 \\
\hline Loss of taste & $28(11.9)$ & $0(0)$ & 0.234 \\
\hline Diarrhea & $14(5.9)$ & $1(5.6)$ & 1 \\
\hline Nausea & $13(5.5)$ & $1(5.6)$ & 1 \\
\hline Vomiting & $4(1.7)$ & $1(5.6)$ & 0.310 \\
\hline Hemoptysis & $2(0.8)$ & $0(0)$ & 1 \\
\hline Headache & $40(16.9)$ & $2(11.1)$ & 0.746 \\
\hline Sore throat & $33(14)$ & $4(22.2)$ & 0.310 \\
\hline Nasal congestion & $14(5.9)$ & $2(11.1)$ & 0.316 \\
\hline Conjunctivitis & $13(5.5)$ & $0(0)$ & 0.608 \\
\hline Asymptomatic & $23(9.7)$ & $1(5.6)$ & 1 \\
\hline \multicolumn{4}{|l|}{ Treatments } \\
\hline Oseltamivir & $58(24.6)$ & $1(5.6)$ & 0.082 \\
\hline Azithromycin & $10(4,2)$ & $2(11.1)$ & 0.205 \\
\hline Clarithromycin & $3(1.3)$ & $0(0)$ & 1 \\
\hline Other antibiotics & $3(1.3)$ & $0(0)$ & 1 \\
\hline $\begin{array}{l}\text { Findings compatible with } \\
\text { Covid-19 in thoracic computed } \\
\text { tomography }\end{array}$ & $51(21.6)$ & $4(22.2)$ & 1 \\
\hline
\end{tabular}

Similarly, in a randomized controlled study conducted by Oriol et al. on patients with mild COVID-19, it was found that hydroxychloroquine use had no effect on the viral load for up to 7 days, and it did not have an effect on the improvement of symptoms or the incidence of hospitalization either (14). Although the increasing number of articles against the use of hydroxychloroquine is evident, there are also studies in the literature that assert that the medication may be beneficial. A study showed that hydroxychloroquine shortened the time of the clinical recovery and decreased the duration of coughing, and fever when compared to a control group (15). In a living systematic review where 32 randomized controlled studies were analyzed, it was reported that the use of hydroxychloroquine decreased the period of the disease up to 4.5 days, but that it increased the frequency of non-serious adverse effects (16). In consequence, the uncertainty in the literature regarding the use of hydroxychloroquine in COVID-19 patients still continues. According to the current study results, we consider that hydroxychloroquine treatment might reduce clinical progression, at least in mild COVID-19 patients.

The reason for the young population of this study is that the Ministry of Health of Turkey determined age of $>50$ years as a criteria for hospitalization at the time of the study, and our study examines patients referred to home isolation. For this reason, since they were already hospitalized, elderly patients were not included in our study. There are many publications in the literature indicating that advanced age is associated with poor prognosis in COVID-19 patients $(17,18)$.

Interestingly, in our study, no significant difference was found in the hospitalization rate of mild COVID-19 patients who smoke compared to non-smokers. According to Francesca Polverino, ACE-2, synthesized by goblet cells due to metaplasia caused by cigarette smoke in epithelial cells, prevents invasion by creating a barrier for the pathogen (19). Similarly, according to the study of Eduardo Hernandez Garduna on 32,583 patients, it was determined that smoking is not a risk factor but is protective for COVID-19 (odds ratio $0.6395 \%$ CI, 0.51-0.77) (20). However, some studies state that smoking will increase the inflammatory response and cytokine storm in patients with COVID-19 and thus have negative effects on the prognosis (21). Based on this inconsistent literature and the results we found in our study, we consider that further studies are needed to determine whether smoking is a risk factor or a protective factor for 


\section{COVID-19.}

The limitation of this study is that it involves a limited patient population due to its single-center nature. The relatively small number of samples decreased its statistical power.

We recommend hospitalization of the patients with COVID-19 compatible thoracic CT appearance regardless of the severity of the infiltration and advanced age as these variables were found to be associated with progression of the disease. Considering that hydroxychloroquine was associated with reduced clinical progression in our study, we think that the use of the drug may be appropriate in mild COVID-19 patients who are recommended home isolation.

\section{Conflict of interest}

There are no conflicts of interest in connection with this paper.

\section{Acknowledgments}

Special thanks to Sümeyra ACAR KURTULUŞ, M.D. for her contribution on data collection process.

\section{References}

1. Timeline: WHO's COVID-19 response [Internet] 2020 [cited 2020 Aug 24] Available from: https://www.who.int/emergencies/diseases/novel-coronavirus2019/interactive-timeline

2. Khan G, Sheek-Hussein M, Al Suwaidi AR, Idris K, AbuZidan FM. Novel coronavirus pandemic: A global health threat. Turk J Emerg Med. 2020 May 27;20(2):55-62. doi: 10.4103/2452-2473.285016.

3. Coronavirus Disease (COVID-19) Situation Reports [Internet]. 2020 [cited 2020 Aug 24] Available from: https://www.who.int/emergencies/diseases/novel-coronavirus2019/situation-reports.

4. Coronavirus Disease 2019 (COVID-19). Centers for Disease Control and Prevention [Internet]. 2020 [cited 2020 Aug 24] Available from: https:/www.cdc.gov/coronavirus/2019ncov/hcp/ clinical-guidance-management-patients.html.

5. Overview | COVID-19 rapid guideline: managing suspected or confirmed pneumonia in adults in the community | Guidance | NICE [Internet]. 2020 [cited 2020 Aug 24] Available from: https://www.nice.org.uk/guidance/ng165

6. Canada PHA of. Clinical Management of Patients with Moderate to Severe COVID-19 - Interim Guidance [Internet]. 2020 [cited 2020 Aug 24] Available from: https://www.canada.ca/en/ publichealth/services/diseases/2019-novel-coronavirusinfection/clinical-management-covid-19.html

7. HPS Website - COVID-19 - guidance for primary care [Internet]. 2020 [cited 2020 Aug 24] Available from: https://www.hps.scot.nhs.uk/web-resources-container/covid19-guidance-for-primary-care/

8. Chinese Center for Disease Control and Prevention [Internet]. 2020 [cited 2020 Aug 24] Available from:
http://www.chinacdc.cn/en/COVID19/

9. COVID-19 Algoritmalar [Internet]. 2020 [cited 2020 Aug 24] Available from: https://covid19bilgi.saglik. gov.tr/tr/algoritmalar

10. Bartsch SM, Ferguson MC, McKinnell JA, O'Shea KJ, Wedlock PT, Siegmund SS, et al. The Potential Health Care Costs and Resource Use Associated With COVID-19 In The United States. Health Aff (Millwood). 2020 Jun;39(6):927-935. doi: 10.1377/hlthaff.2020.00426.

11. Li X, Wang Y, Agostinis P, Rabson A, Melino G, Carafoli E, et al. Is hydroxychloroquine beneficial for COVID-19 patients? Cell Death Dis. 2020 Jul 8;11(7):512. doi: 10.1038/s41419020-2721-8.

12. Boulware DR, Pullen MF, Bangdiwala AS, Pastick KA, Lofgren SM, Okafor EC, et al. A Randomized Trial of Hydroxychloroquine as Postexposure Prophylaxis for Covid19. N Engl J Med. 2020 Aug 6;383(6):517-525. doi: 10.1056/NEJMoa2016638.

13. Tang W, Cao Z, Han M, Wang Z, Chen J, Sun W, et al. Hydroxychloroquine in patients with mainly mild to moderate coronavirus disease 2019: open label, randomised controlled trial. BMJ. 2020 May 14;369:m1849. doi: 10.1136/bmj.m1849.

14. Mitjà $\mathrm{O}$, Corbacho-Monné $M$, Ubals $M$, Tebe $C$, Peñafiel $J$, Tobias A, et al; BCN PEP-CoV-2 RESEARCH GROUP. Hydroxychloroquine for Early Treatment of Adults with Mild Covid-19: A Randomized-Controlled Trial. Clin Infect Dis. 2020 Jul 16: ciaa1009. doi: 10.1093/cid/ciaa1009.

15. Chen Z, Hu J, Zhang Z, Jiang S, Han S, Yan D, et al. Efficacy of hydroxychloroquine in patients with COVID-19: results of a randomized clinical trial. MedRxiv. 2020. doi: https://doi.org/10.1101/2020.03.22.20040758.

16. Siemieniuk RA, Bartoszko JJ, Ge L, Zeraatkar D, Izcovich A, Kum E, et al. Drug treatments for covid-19: living systematic review and network meta-analysis. BMJ. 2020 Jul 30;370:m2980. doi: 10.1136/bmj.m2980.

17. Asfahan S, Deokar K, Dutt N, Niwas R, Jain P, Agarwal M. Extrapolation of mortality in COVID-19: Exploring the role of age, sex, co-morbidities and health-care related occupation. Monaldi Arch Chest Dis. 2020 May 21;90(2). doi: 10.4081/monaldi.2020.1325.

18. Aksel G, İslam MM, Algın A, Eroğlu SE, Yaşar GB, Ademoğlu E, et al. Early predictors of mortality for moderate to severely ill patients with Covid-19. Am J Emerg Med. 2020 Aug 28: S0735-6757(20)30770-1. doi: 10.1016/j.ajem.2020.08.076.

19. Polverino F. Cigarette Smoking and COVID-19: A Complex Interaction. Am J Respir Crit Care Med. 2020 Aug 1;202(3):471-472. doi: 10.1164/rccm.202005-1646LE.

20. Hernández-Garduño E. Obesity is the comorbidity more strongly associated for Covid-19 in Mexico. A case-control study. Obes Res Clin Pract. 2020 Jul-Aug;14(4):375-379. doi: 10.1016/j.orcp.2020.06.001.

21. Kaur G, Lungarella G, Rahman I. SARS-CoV-2 COVID-19 susceptibility and lung inflammatory storm by smoking and vaping. J Inflamm (Lond). 2020 Jun 10; 17:21. doi: 10.1186/s12950-020-00250-8. 